\title{
Critical evaluation of vinflunine in the treatment of refractory metastatic urothelial carcinoma
}

\author{
This article was published in the following Dove Press journal: \\ Open Access Journal of Urology \\ 29 June 2010 \\ Number of times this article has been viewed
}

\section{Armand Morel \\ Denis Talbot \\ 'Department of Medical Oncology, University of Oxford, Oxford, Oxfordshire, UK}

\begin{abstract}
Urothelial carcinoma (UC) accounts for 5\% to $10 \%$ of malignancies in men in Europe and the United States. For locally advanced or metastatic disease, there are two standard firstline chemotherapy regimens: MVAC (methotrexate, vinblastine, doxorubicin, cisplatin) and gemcitabine/cisplatin. For refractory disease, there is currently no standard treatment. Vinflunine, a second-generation Vinca alkaloid, is the first chemotherapeutic agent to be evaluated in a large UC second-line population. This review discusses the pre-clinical and clinical data published, and compares vinflunine to alternative single agents and combination regimens tested in this setting. Based on the results of the phase II and III clinical trials, there appears to be sufficient evidence to support the use of vinflunine in the second-line setting.
\end{abstract}

Keywords: vinflunine, Vinca alkaloid, urothelial carcinoma, transitional cell carcinoma, bladder cancer

\section{Introduction}

Bladder cancer is the ninth most common cancer worldwide, and accounted for an estimated 14,330 deaths in 2009 in the United States. ${ }^{1}$ It affects men in the majority (77\%) of cases $^{2}$ with $63 \%$ of cases occurring in the developed world. In Europe and the United States bladder cancer accounts for $5 \%$ to $10 \%$ of malignancies in men. ${ }^{3}$ Cigarette smoking is the primary risk factor, ${ }^{4-10}$ but other risk factors include exposure to arsenic, ${ }^{11,12}$ aromatic amines, ${ }^{13}$ and aniline dyes. ${ }^{14}$ Additionally, chronic Schistosoma haematobium infection has been linked to the squamous cell type of bladder carcinoma, explaining the higher rates observed in parts of Africa and the Middle East. ${ }^{15}$ Urothelial or transitional cell carcinoma (UC) accounts for $95 \%$ of bladder tumors, with the remaining cases consisting of squamous cell carcinoma and adenocarcinoma. ${ }^{16}$

While the majority of UC cases present as superficial disease, ${ }^{17} 15 \%$ to $25 \%$ are at high risk for progression to muscle invasion. ${ }^{18}$ For locally advanced or metastatic disease, there are two standard first-line chemotherapy regimens: MVAC (methotrexate, vinblastine, doxorubicin, cisplatin) and gemcitabine/cisplatin. Unfortunately, the median overall survival (OS) following MVAC therapy is only 14.8 months and gemcitabine + cisplatin is associated with 7.4 months median time to progressive disease (TTP) and 13.8 months OS. ${ }^{19}$ Although many patients are not eligible for further treatment due to poor performance status (PS), there is nonetheless an unmet clinical need for effective second-line therapy for patients having progressed on these platinum-based regimens.

Various single agents and combination regimens have been evaluated in clinical trials. Single agents having clinical activity include docetaxel, ${ }^{20}$ paclitaxel,,${ }^{21-23}$ pemetrexed, ${ }^{24,25}$ 
bortezomib, ${ }^{26,27}$ and vinblastine. ${ }^{28}$ Combination regimens have often included taxanes combined with a second drug such as carboplatin ${ }^{29-31}$ or gemcitabine. ${ }^{32-36}$ Unfortunately, many of these studies have limited efficacy.

Vinflunine (VFL), a novel microtubule inhibitor, is undergoing clinical evaluation in this setting. Studies reported in the literature show encouraging results with VFL as a single agent in the treatment of refractory UC. This review discusses VFL's safety and efficacy profile in this setting, and compares it to competing single-agent and combination regimens.

\section{Pharmacology and mechanism of action \\ Chemistry of vinflunine}

The origins of VFL (Javlor ${ }^{\circledR}$; Pierre Fabre Medicament Laboratories), a third-generation Vinca alkaloid, date back to 1958 when vinblastine was first isolated from the Madagascan periwinkle Catharanthus roseus (also known as Vinca rosea). ${ }^{37}$ The discovery of vincristine and vinorelbine soon followed. VFL was discovered in 1988 when novel superacidic chemistry was applied to vinorelbine, allowing selective addition of two fluorine atoms at the 20 ' position of the catharanthine moiety to create 20',20'-difluoro-3',4'dihydrovinorelbine, or VFL (see Figure 1). Previously, the 20 ' site had been inaccessible using classical synthetic chemistry. ${ }^{38}$

In contrast to other microtubule inhibitors, VFL is freely water-soluble. Thus, there is no risk of solvent-related hypersensitivity reactions. Phase I trials showed a mean terminal half-life of VFL to be 40 hours and a terminal half-life of 4 to 6 days for 4-O-deacetylvinflunine, VFL's only active metabolite. The volume of distribution is approximately 1,517 L suggesting significant tissue distribution. Excretion is both fecal (two thirds) and urinary (one third), an important consideration given that many patients with advanced bladder cancer suffer renal impairment. ${ }^{39-41}$

\section{Mechanism of action}

Microtubules make up the mitotic spindle required for chromosome separation and cell division, and are the target of anti-cancer agents such as Vinca alkaloids and taxanes. While taxanes stabilize microtubules resulting in "frozen mitosis", Vinca alkaloids exert their antiproliferative effect largely by preventing tubulin polymerization. This destabilizes microtubules and prevents mitotic progression. ${ }^{42}$ At high concentrations, they depolymerize microtubules and destroy mitotic spindles; at lower concentrations, they suppress the rate and

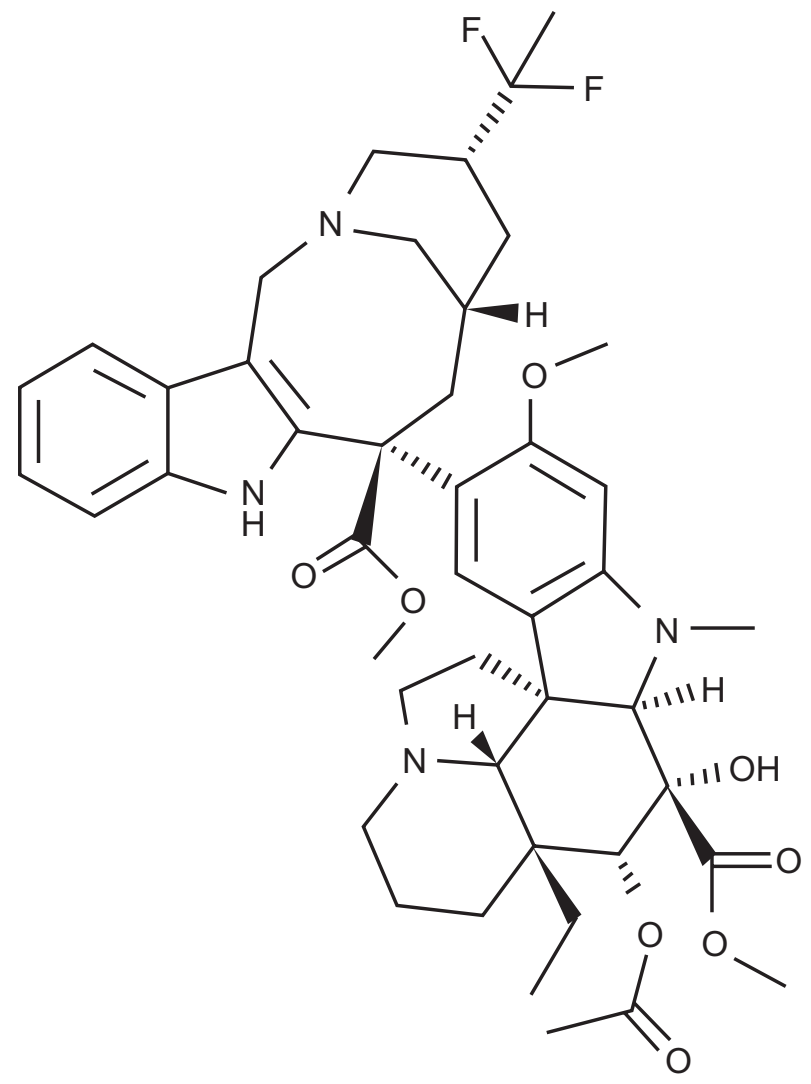

Figure I Structure of vinflunine.

extent of microtubule treadmilling, resulting in mitotic block and apoptotic cell death. ${ }^{43,44}$

\section{Advantages relative to other Vinca alkaloids}

VFL interacts with microtubules in a different way to other Vinca alkaloids. It binds to tubulin less readily, requiring 3- to 17-fold higher concentrations for similar biological effects relative to other members of its class. ${ }^{45}$ Consequently fewer and smaller spiral polymers are induced and its interaction with tubulin is more readily reversible. ${ }^{46}$ These different binding properties represent an advantage for VFL because they confer greater antitumor efficacy ${ }^{45}$ and reduced neurotoxicity, ${ }^{43}$ an important clinical consideration. The precise reason for VFL's superior antitumor efficacy is unknown, but may involve high intracellular accumulation and interaction with undefined targets. ${ }^{47}$

A general problem with the Vinca alkaloid class of drugs is the development of multidrug resistance (MDR) due to over-expression of P-glycoprotein (Pgp), a membrane efflux pump. Although VFL does induce Pgp-mediated resistance, cross-resistance to VFL occurred at a lower rate than to other Vinca alkaloids in human cancer cell lines including 
leukemia, breast carcinoma and bladder carcinoma. ${ }^{48}$ Additionally, mice implanted with P388 murine leukemia cells developed complete resistance to vinorelbine at 11 weeks, compared to 36 weeks for VFL. ${ }^{49}$

\section{Vascular-disrupting and anti-angiogenic action}

In addition to its anti-proliferative effects, studies have demonstrated that VFL has vascular-disrupting and anti-angiogenic properties in vitro. ${ }^{50}$ In 2006 Kruczynski et al showed that in vitro VFL disrupts the network of capillary-like structures and inhibits endothelial cell migration and capacity to organize. These experiments were done at concentrations that only mildly affected endothelial cell proliferation. ${ }^{50}$ In addition, in vivo studies in mice showed reduced numbers of liver metastases after intrasplenic injection of LS174T (tumor) cells. Moreover, at doses 20- to 40-fold lower than its maximal therapeutic dose (MTD), VFL inhibited bFGF-induced angiogenesis in Matrigel $^{\mathrm{TM}}$ implants. ${ }^{50}$

\section{Pre-clinical properties Efficacy}

VFL has shown higher in vivo anticancer activity than other microtubule inhibitors. In mice implanted with P388 murine leukemia cells, VFL has shown the maximum antitumor activity and survival prolongation compared to the other Vinca alkaloids. ${ }^{51}$ Hill et al ${ }^{52}$ treated nude mice implanted with a series of human tumor xenografts, and reported a $64 \%$ overall response rate with VFL compared to $27 \%$ with vinorelbine. In another important study Bonfil et al reported complete tumor eradication and $100 \%$ survival at 60 days when VFL (5-20 mg/kg) was administered intraperitoneally into mice that had had murine bladder cancer cells (MB49) implanted transurethrally. ${ }^{53}$ The success of these studies led to the beginning of clinical trials by Bennouna et $\mathrm{al}^{39}$ and others.

\section{Toxicity profile}

Common toxicities of Vinca alkaloids include myelosuppression and neuropathy due to axonal degeneration resulting in peripheral neuropathy typically beginning as paresthesia of the fingers and toes that spreads proximally in a 'glove and stocking' distribution. ${ }^{54}$ Compared to other Vinca alkaloids, VFL has a better safety profile because it binds tubulin weakly and reversibly. These characteristics may explain the smaller degree of neuropathy and noncumulative nature of VFL-related toxicities, respectively. In most cases, neuropathy resolves after drug withdrawal. ${ }^{47}$

\section{Synergistic effects}

In a pre-clinical study evaluating in vitro activity against a human non-small-cell lung cancer (NSCLC) cell line, VFL demonstrated synergistic cytotoxicity with cisplatin, mitomy$\operatorname{cin} \mathrm{C}$, doxorubicin and 5-fluorouracil (5-FU). Similar results were obtained against human leukemia cells. Importantly, no antagonistic drug interactions occurred, ${ }^{55}$ suggesting the potential for combination therapies. When these synergies were examined in vivo using P388 murine leukemia cells grafted intravenously, the authors found superior activity for combinations of single intraperitoneal doses of VFL with either doxorubicin, mitomycin $\mathrm{C}$, cisplatin or F $11782 .{ }^{56}$ VFL's synergistic effects with cisplatin and 5-FU were further evaluated in a transplantable murine colon adenocarcinoma model, MAC 29. While synergy was demonstrated with cisplatin, this was not shown with 5 -FU. ${ }^{57}$

VFL may also exhibit synergy with radiotherapy. Microtubule inhibitors such as VFL synchronize cells in the mitotic phase, rendering them more sensitive to radiation. ${ }^{58}$ Indeed, Simoens et $\mathrm{al}^{59}$ found a concentration-dependent $\mathrm{G} 2 / \mathrm{M}$ block and consequent radiosensitization of different tumor cell lines.

\section{Clinical trials}

Because of its broader spectrum of activity and advantages over other Vinca alkaloids, VFL has been evaluated as monotherapy and as combination chemotherapy in a number of different cancers, including breast cancer, ${ }^{60-66}$ NSCLC, ${ }^{67-71}$ small cell lung cancer (SCLC), ${ }^{72,73}$ prostate cancer, ${ }^{74}$ gastric cancer, ${ }^{75}$ malignant pleural mesothelioma ${ }^{76-78}$ and renal cell carcinoma. ${ }^{79}$ The recommended dose for clinical studies is $320 \mathrm{mg} / \mathrm{m}^{2}$ administered intravenously every 21 days. For patients with a lower performance status or those having received prior pelvic irradiation, the dose is reduced to $280 \mathrm{mg} / \mathrm{m}^{2}{ }^{69,80}$ Prior pelvic irradiation is reported to exacerbate hematological toxicities. ${ }^{81}$ In the literature, there are currently two phase II and one phase III study reported of VFL as second-line therapy in metastatic UC.

\section{Phase I trials}

On the basis of strong pre-clinical data, VFL was evaluated in several phase I trials using a variety of schedules in patients with solid tumors. Bennouna et $\mathrm{al}^{39}$ conducted a study in 31 patients with advanced malignancy. Patients were treated with escalating doses from 30 to $400 \mathrm{mg} / \mathrm{m}^{2}$ VFL 3-weekly, and the authors reported a maximum tolerated dose (MTD) of $400 \mathrm{mg} / \mathrm{m}^{2}$. Adverse events reported were mucositis, constipation and neutropenia of short duration. Three partial 
responses (PR) were observed. The authors recommended a dose of $350 \mathrm{mg} / \mathrm{m}^{2}$ 3-weekly.

In 2006, Johnson et $\mathrm{al}^{41}$ reported a similar study in 16 patients with advanced solid tumors. VFL was given 3-weekly on days 1 and 8 as a 10-minute infusion. A maximum tolerated dose (MTD) was established at $190 \mathrm{mg} / \mathrm{m}^{2}$ based on 2 of 4 patients developing constipation and neutropenia which were dose limiting. There were no objective responses. The authors recommended a dose of $170 \mathrm{mg} / \mathrm{m}^{2}$ on days 1 and 8 3-weekly for future studies.

\section{Phase II trials in urothelial carcinoma}

Based on the safety data reported in phase I trials and the complete tumor eradication reported in a murine bladder carcinoma model, ${ }^{53}$ phase II trials of vinflunine in UC were begun. Culine et $\mathrm{al}^{82}$ conducted an open-label, multicenter, noncomparative phase II study in 51 patients from 16 European centers with advanced UC who failed first-line platinum-based regimens. Patients were treated with $320 \mathrm{mg} / \mathrm{m}^{2}$ VFL. The primary endpoint was efficacy as measured by tumor response rate; secondary objectives were duration of response, progression-free survival (PFS), OS, and treatment-related toxicity. Eligible patients were aged $\geq 18$ years with a Karnofsky performance status (KPS) $\geq 80$. Tumor response was assessed after the initial 2 cycles. Nine patients (18\%; 95\% CI: 8.4\%-30.9\%) achieved PR and 25 achieved stable disease (SD) for an overall disease control rate of $(\mathrm{PR}+\mathrm{SD})$ of $67 \%$ (95\% CI: $52.1 \%-79.3 \%)$. Additionally, objective response was seen in 8 of 34 patients $(24 \%)$ previously treated for metastatic disease and in 1 of $17(6 \%)$ patients previously treated in the neoadjuvant or adjuvant setting. The median duration of response was 9.1 months (95\% CI: 4.2-15.0) and median PFS was 3.0 months (95\% CI: 2.4-3.8). Median OS was 6.6 months (95\% CI: 4.8-7.6). Significant toxicities included grade 3-4 leukopenia in $45 \%$ patients and grade 3-4 neutropenia in $67 \%$ patients. Five patients $(10 \%)$ experienced febrile neutropenia, 2 of whom died of drug related toxicity. Importantly, grade 3-4 sensory neuropathy was not observed, nor was grade 3-4 renal function impairment.

In 2009, Vaughn et al ${ }^{83}$ reported results of a similar study done in the United States evaluating the safety and efficacy of VFL in patients having progressed within 12 months after platinum-based chemotherapy. Eligibility criteria were similar to the Culine et al trial, ${ }^{82}$ and patients were treated with $320 \mathrm{mg} / \mathrm{m}^{2}$ VFL unless they had impaired renal function, KPS $\geq 80$, prior pelvic irradiation, or were aged $\geq 75$ years. These patients received an initial dose of $280 \mathrm{mg} / \mathrm{m}^{2}$, which was escalated to $320 \mathrm{mg} / \mathrm{m}^{2}$ in cycle 2 if well tolerated. Of 175 patients enrolled, 151 received at least one dose of VFL. The primary objective was response rate as defined by an independent response review committee (IRRC); secondary endpoints included duration of response, time to response, disease control rate, PFS, OS, and toxicity. Twenty-two of 151 subjects achieved PR (15\%; 95\% CI: 9\%-21\%) and 64 achieved SD (42\%), for an overall response rate (ORR) of $14.6 \%$ (95\% CI: 9.4\%-21.2\%). The median duration of response was 6.0 months (95\% CI: 5.4-9.5 months), and the median duration of disease stabilization was 4.0 months (95\% CI: 3.5-4.7 months). Median PFS was 2.8 months, and median OS was 8.2 months. The main toxicity of VFL was hematologic: grade 3 or 4 neutropenia was reported in 58\% patients, leucopoenia in $49 \%$, and anemia in 16\%. Grade 3-4 febrile neutropenia was seen in 10 patients (7\%). Grade 3-4 non-hematologic toxicities included constipation (17\%), fatigue (13\%), ileus (5\%), and abdominal pain (5\%). Patients with renal impairment had a similar safety profile, and VFL did not damage renal function.

\section{Phase III trials in urothelial carcinoma}

On the basis of the two phase II trials, Bellmunt et al ${ }^{81}$ conducted a randomized, multinational, phase III trial of VFL and best supportive care (BSC) as second-line treatment in patients progressing after platinum-containing chemotherapy. Three hundred and seventy patients were recruited: 253 were randomized to the VFL + BSC arm, and 117 to the BSC only arm. Eligibility criteria were similar to the phase II trials. Patients with Eastern Cooperative Oncology Group (ECOG) performance status (PS) 0 were given $320 \mathrm{mg} / \mathrm{m}^{2} \mathrm{VFL}$, while patients with ECOG PS 0 and prior pelvic irradiation or ECOG PS 1 were given $280 \mathrm{mg} / \mathrm{m}^{2} \mathrm{VFL}$. The primary objective was obtaining a median 2-month survival advantage favoring the VFL + BSC group. This was achieved (6.9 versus 4.6 months) in both the intent-to-treat and eligible population, but the difference in OS was only significant $(P=0.040)$ in the eligible population. The intent-to-treat population was the randomly assigned population, and the eligible population excluded 13 patients with at least one major protocol violation at baseline. Secondary endpoints were ORR, disease control rate and duration, and median PFS. Sixteen (8.6\%) patients achieved PR with a 7.4 months (95\% CI: 4.5-17.0) median duration of response, and 86 (46.5\%) achieved SD. Significant (grade 3-4) toxicities 
were primarily hematologic, including neutropenia (50\%), febrile neutropenia (6\%) and anemia (19\%).

The VINCENT (vinflunine in cisplatin-ineligible patients) phase III clinical trial is currently ongoing. It compares gemcitabine plus VFL versus gemcitabine plus placebo in chemotherapy-naïve patients. The target accrual is 450 patients. ${ }^{84}$

\section{Safety and tolerability}

In all phase II and III trials evaluating VFL in UC the drug was reported to have an acceptable safety profile. The main grade 3-4 toxicities were hematologic (see Table 1). Common non-hematologic adverse effects were fatigue and constipation. Importantly, the dose-limiting neurotoxicity seen in other Vinca alkaloids was not observed in VFL, and toxicities were non-cumulative. In general, the safety profile of VFL compared relatively favorably to that of other single agents (see Table 2).

\section{The potential role of vinflunine in the management of urothelial carcinoma}

The wide variety of single agents (see Table 2) and combination of agents (see Table 3) studied in the second-line setting of metastatic UC begs the question: is there sufficient evidence to recommend a standard second-line treatment in metastatic cisplatin-resistant UC?

\section{Single agents}

Second-line single agents, mainly studied in phase II trials, have not demonstrated impressive response rates (0\%-27.7\%), median TTP, or OS. Molecularly targeted agents in particular have generally fared poorly, as exemplified by the trials of bortezomib ${ }^{26,27}$ and lapatinib. ${ }^{85}$ In addition, many studies enrolled relatively few patients, making it difficult to draw conclusions about efficacy. VFL has been the only drug evaluated in a randomized controlled phase III trial that has demonstrated moderate activity and a good safety profile.

\section{Combination regimens}

Combination regimens generally offer the compromise of higher response rates and longer OS in exchange for more severe toxicities. In assessing the potential role of VFL it is important to consider combinations for which there is most evidence. Gemcitabine/paclitaxel has been one of the more extensively studied regimens recently, particularly in Japan. Different doses and schedules have been tried, with response rates ranging from $30 \%$ to $70 \%$ and median OS of 10.3 to 14.4 months. Reported grade 3-4 toxicities have been mainly hematological, but also include peripheral neuropathy and allergic reactions to paclitaxel. Kanai et $a 1^{35}$ observed grade 3-4 neutropenia in 6 patients $(30 \%)$, anemia in 3 patients $(15 \%)$, and thrombocytopenia in 1 patient $(5 \%)$. No instances of grade $3-4$ peripheral neuropathy were reported. Matsumoto et $\mathrm{al}^{34}$ also observed

Table I Grade 3-4 adverse events in patients with advanced or metastatic urothelial carcinoma treated with vinflunine

\begin{tabular}{|c|c|c|c|}
\hline Trial description & Vinflunine, phase II & Vinflunine, phase II & VFL + BSC vs BSC, phase III \\
\hline Investigators & Culine $^{82}$ & Vaughn ${ }^{83}$ & Bellmunt ${ }^{81}$ \\
\hline \multirow[t]{2}{*}{ Dose and schedule } & $320 \mathrm{mg} / \mathrm{m}^{2} \mathrm{IV}$ every $2 \mathrm{I}$ days & Dose escalation of 280 & Two arms with 280 or \\
\hline & & to $320 \mathrm{mg} / \mathrm{m}^{2}$ IV every 2 I days & $320 \mathrm{mg} / \mathrm{m}^{2}$ IV every $2 \mathrm{I}$ days \\
\hline Hematologic & No patients (\%) & No patients (\%) & No patients (\%) \\
\hline Anemia & $7(14)$ & $23(15.5)$ & $47(19.1)$ \\
\hline Leukopenia & $23(45)$ & $73(49.3)$ & NR \\
\hline Neutropenia & $34(67)$ & $86(58.1)$ & $123(50.0)$ \\
\hline Thrombocytopenia & $3(6)$ & $5(3.4)$ & $14(5.7)$ \\
\hline Febrile neutropenia & $5(10)$ & $10(6.6)$ & $15(6.0)$ \\
\hline Neutropenia with infection & $3(6)$ & $3(2.0)$ & NR \\
\hline \multicolumn{4}{|l|}{ Nonhematologic toxicities } \\
\hline Nausea & $2(4)$ & $5(3.3)$ & $6(2.4)$ \\
\hline Vomiting & $3(6)$ & $3(2.0)$ & $7(2.8)$ \\
\hline Constipation & $4(8)$ & $25(16.6)$ & $40(16.1)$ \\
\hline Stomatitis/mucositis & $3(6)$ & $5(3.3)$ & $4(1.6)$ \\
\hline Asthenia/fatigue & $5(10)$ & $19(12.6)$ & $48(19.3)$ \\
\hline Abdominal pain & $4(8)$ & $7(4.6)$ & $10(4.0)$ \\
\hline Peripheral sensory neuropathy & 0 & $\mathrm{I}(0.7)$ & $3(1.2)$ \\
\hline Injection site reactions & 0 & $\mathrm{I}(0.7)$ & $\mathrm{I}(0.4)$ \\
\hline Myalgia & $2(4)$ & $4(2.6)$ & $8(3.2)$ \\
\hline
\end{tabular}

Abbreviation: NR, not reported. 
Table 2 Trials of single agents in second-line treatment of advanced or metastatic urothelial carcinoma

\begin{tabular}{|c|c|c|c|c|c|c|}
\hline Agent & $\begin{array}{l}\text { No of } \\
\text { evaluable } \\
\text { patients }\end{array}$ & $\begin{array}{l}\text { ORR: patients } \\
\text { responding (\%) }\end{array}$ & $\begin{array}{l}\text { Median } \\
\text { TTP (months) }\end{array}$ & $\begin{array}{l}\text { Median } \\
\text { OS (months) }\end{array}$ & $\begin{array}{l}\text { Main grade } 3-4 \text { toxicities: } \\
\text { no patients }(\%)\end{array}$ & Reference \\
\hline Vinflunine & 51 & $9(18 \%)$ & 3.0 & 6.6 & $\begin{array}{l}34(67 \%) \text { neutropenia; } \\
23(45 \%) \text { leukopenia; } \\
7(14 \%) \text { anemia }\end{array}$ & Culine $^{82}$ \\
\hline Vinflunine & $|5|$ & $22(15 \%)$ & 2.8 & 8.2 & $\begin{array}{l}86(58.1 \%) \text { neutropenia; } \\
73(49 \%) \text { leukopenia; } \\
23(16 \%) \text { anemia }\end{array}$ & Vaughn ${ }^{83}$ \\
\hline Vinflunine & 370 & $16(8.6 \%)$ & 3.0 & 6.9 & $\begin{array}{l}\text { I23 (50\%) neutropenia; } \\
47 \text { (19\%) anemia }\end{array}$ & Bellmunt $^{81}$ \\
\hline Vinblastine & 28 & $5(18 \%)$ & $N / A$ & $N / A$ & $\mathrm{~N} / \mathrm{A}$ & Blumenreich $^{28}$ \\
\hline Paclitaxel & 14 & I (7.I\%) & $\mathrm{N} / \mathrm{A}$ & $\mathrm{N} / \mathrm{A}$ & $\begin{array}{l}\text { Hematological toxicities in } 23 \\
\text { of } 42 \text { courses; } 2 \text { (14\%) with } \\
\text { other grade } 3-4 \text { toxicities }\end{array}$ & Papamichael $^{21}$ \\
\hline Paclitaxel & 31 & $3(10 \%)$ & 2.2 & 7.2 & $\begin{array}{l}4(13 \%) \text { anemia; } 2(7 \%) \\
\text { asthenia }\end{array}$ & Vaughn ${ }^{22}$ \\
\hline Paclitaxel & 45 & $4(9 \%)$ & 3 & 7 & $\mathrm{~N} / \mathrm{A}$ & Joly ${ }^{23}$ \\
\hline Docetaxel & 30 & 4 (I3.3\%) & $N / A$ & 9 & $18(60 \%)$ & McCaffrey ${ }^{20}$ \\
\hline Ifosfamide & 20 & I (5\%) & 6.0 & 8.0 & $2(10 \%)$ & Pronzato $^{87}$ \\
\hline Ifosfamide & 56 & II (20\%) & 2.2 & 5.1 & $\mathrm{~N} / \mathrm{A}$ & Witte $^{88}$ \\
\hline Topotecan & 44 & $4(9.1 \%)$ & $\mathrm{I} .4$ & 6.3 & $\begin{array}{l}34(77 \%) \text { leukopenia; } \\
27(61 \%) \text { anemia; } \\
19(43 \%) \text { thrombocytopenia }\end{array}$ & Witte $^{89}$ \\
\hline Pyrazoloacridine & 14 & 0 & $N / A$ & 9 months & $\begin{array}{l}8(57 \%) \text { neutropenia; } \\
2(14 \%) \text { thrombocytopenia }\end{array}$ & $\operatorname{Dodd}^{90}$ \\
\hline Piritrexim & 27 & $2(7 \%)$ & 2.1 & 7.0 & $\begin{array}{l}4(15 \%) \text { thrombocytopenia; } \\
3 \text { (II\%) anemia; } 5(19 \%) \\
\text { neuropathy; } 2(7 \%) \\
\text { hepatotoxicity; } 2 \text { (7\%) nausea }\end{array}$ & Roth'1 \\
\hline Piritrexim & 22 & 0 & $N / A$ & $N / A$ & $6(27 \%)$ & Lassiter $^{92}$ \\
\hline Oxaliplatin & 20 & I (5\%) & $N / A$ & $N / A$ & II (55\%) & Winquist $^{93}$ \\
\hline Pemetrexed & 47 & $13(27.7 \%)$ & 2.9 & 9.6 & $\begin{array}{l}4(9 \%) \text { thrombocytopenia; } \\
4(9 \%) \text { neutropenia; } 2(4 \%) \\
\text { anemia; } 3(6 \%) \text { fatigue; } 2(4 \%) \\
\text { diarrhea }\end{array}$ & Sweeney ${ }^{24}$ \\
\hline Pemetrexed & 12 & I (8\%) & $N / A$ & $N / A$ & $\begin{array}{l}3(23 \%) \text { anemia; } 3(23 \%) \\
\text { neutropenia; } 3(23 \%) \\
\text { thrombocytopenia }\end{array}$ & Galsky $^{25}$ \\
\hline Bortezomib & 21 & 0 & 1.9 & 3.5 & $15(7 \mid \%)$ & Gomez-Abuin ${ }^{26}$ \\
\hline Bortezomib & 25 & 0 & 1.4 & 5.7 & $5(2 \mid \%)$ hematological toxicity & Rosenberg ${ }^{27}$ \\
\hline Gemcitabine & 44 & II (25\%) & 3.1 & 12.6 & $\begin{array}{l}2 I \text { ( } 48 \%) \text { neutropenia; } 4 \text { (9\%) } \\
\text { anorexia }\end{array}$ & Akaza ${ }^{94}$ \\
\hline $\begin{array}{l}\text { Epothilone B } \\
\text { analog BMS-247550 } \\
\text { (ixabepilone) }\end{array}$ & 45 & $5(11.9 \%)$ & 2.7 & 8.0 & $\begin{array}{l}16(36 \%) \text { granulocytopenia; } \\
5 \text { (II\%) thrombocytopenia; } \\
3 \text { (7\%) sensory neuropathy; } \\
5 \text { (1 I\%) fatigue; } 4 \text { ( } 9 \%) \\
\text { dehydration }\end{array}$ & Dreicer ${ }^{95}$ \\
\hline Irinotecan & 40 & $2(5 \%)$ & 2.1 & 5.4 & N/A & Beer $^{96}$ \\
\hline Lapatinib & 59 & I (I.7\%) & 2.0 & 4.1 & $\begin{array}{l}4(7 \%) \text { vomiting; } 2(3 \%) \\
\text { diarrhea; } 2 \text { (3\%) dehydration; } \\
2(3 \%) \text { hyponatremia }\end{array}$ & Wulfing ${ }^{85}$ \\
\hline
\end{tabular}

Abbreviations: N/A, not available or not reported; ORR, overall response rate; OS, overall survival; TTP, time to progression.

mainly hematologic toxicities as well as hypersensitivity reactions to paclitaxel. Of the 10 patients in the study, 5 developed grade 3 neutropenia and 1 experienced grade 4 thrombocytopenia. Seven patients experienced minor (lower than grade 3 ) hypersensitivity reactions to paclitaxel, suggesting that allergic reactions are a major limitation of this regimen. Sternberg et $\mathrm{al}^{32}$ reported grade 3-4 neutropenia in 13 patients $(32 \%)$ and febrile neutropenia in 3 patients (7\%). Granulocyte colony-stimulating factor was given to 10 patients $(24 \%)$. Suyama et $\mathrm{al}^{36}$ reported 15 patients 
Table 3 Trials of combination chemotherapy in second-line treatment of advanced or metastatic urothelial carcinoma

\begin{tabular}{|c|c|c|c|c|c|}
\hline Agents & $\begin{array}{l}\text { No of } \\
\text { evaluable } \\
\text { patients }\end{array}$ & $\begin{array}{l}\text { ORR: patients } \\
\text { responding } \\
(\%)\end{array}$ & $\begin{array}{l}\text { Median } \\
\text { TTP } \\
\text { (months) }\end{array}$ & $\begin{array}{l}\text { Median OS } \\
\text { (months) }\end{array}$ & Reference \\
\hline Paclitaxel, cisplatin, methotrexate & 25 & $10(40 \%)$ & NR & 3.7 & $\mathrm{Tu}^{97}$ \\
\hline 5-Fluorouracil, cisplatin, interferon-alpha & 40 & $5(12.5 \%)$ & 2.3 & 4.8 & De Mulder ${ }^{98}$ \\
\hline Docetaxel, ifosfamide & 20 & $4(25 \%)$ & NR & 4.0 & Krege $^{99}$ \\
\hline Gemcitabine, paclitaxel & 40 & $24(60 \%)$ & 6.4 & 14.4 & Sternberg ${ }^{32}$ \\
\hline Gemcitabine, paclitaxel & 27 & $12(44 \%)$ & 11.0 & 13.0 & Fechner $^{33}$ \\
\hline Gemcitabine, paclitaxel & 10 & $7(70 \%)$ & 4.1 & 10.3 & Matsumoto ${ }^{34}$ \\
\hline Gemcitabine, paclitaxel & 20 & $6(30 \%)$ & 4.5 & 11.5 & $\mathrm{Kanai}^{35}$ \\
\hline Gemcitabine, paclitaxel & 30 & $10(33.3 \%)$ & 5.5 & 11.3 & Suyama ${ }^{36}$ \\
\hline Gemcitabine, ifosfamide & 34 & $7(21 \%)$ & 4.0 & 9.0 & Pectasides ${ }^{100}$ \\
\hline Cisplatin, gemcitabine, ifosfamide & 49 & $20(40.8 \%)$ & NR & 9.5 & Pagliaro ${ }^{101}$ \\
\hline Gemcitabine, docetaxel & 29 & $5(17 \%)$ & NR & 7.7 & Dreicer $^{102}$ \\
\hline Oxaliplatin, fluorouracil, folinic acid (FOLFOX-4) & 16 & $3(19 \%)$ & NR & 4.0 & Di Lorenzo ${ }^{103}$ \\
\hline Paclitaxel, carboplatin & 44 & $7(16 \%)$ & 4.0 & 6.0 & Vaishampayan ${ }^{29}$ \\
\hline Paclitaxel, carboplatin & 31 & $10(32.3 \%)$ & 3.7 & 7.9 & Kouno ${ }^{30}$ \\
\hline Paclitaxel, carboplatin & 18 & $6(33 \%)$ & 4.0 & II.0 & Soga ${ }^{31}$ \\
\hline Paclitaxel, ifosfamide, nedaplatin & 32 & $24(75 \%)$ & 8.0 & 22.0 & Shinohara ${ }^{104}$ \\
\hline Paclitaxel, cisplatin & 28 & $10(36 \%)$ & 6.2 & 10.3 & Uhm $^{105}$ \\
\hline Gemcitabine, ifosfamide & 23 & $5(22 \%)$ & NR & 4.8 & $\operatorname{Lin}^{106}$ \\
\hline Methotrexate, vinblastine, doxorubicin, cisplatin & 30 & $9(30 \%)$ & 5.3 & 10.9 & $\mathrm{Han}^{107}$ \\
\hline
\end{tabular}

Abbreviations: NR, not reported; ORR, overall response rate; OS, overall survival; TTP, time to progression.

(45\%) experiencing grade 3-4 neutropenia, all of whom responded well to granulocyte colony-stimulating factor. Peripheral neuropathy occurred in 19 patients: 2 cases $(6 \%)$ were grade 3 and 17 (52\%) were grade 2 .

The paclitaxel/carboplatin combination has also yielded good response rates, but fared the worst in terms of OS in the largest study. ${ }^{29}$ Toxicities were also significant: 28 patients (64\%) experienced grade 3-4 hematologic toxicities, and 11 patients $(25 \%)$ experienced neurologic toxicities.

Given the relatively large number of patients enrolled in phase II and III clinical trials in UC and clinical efficacy and safety data available, there appears to be sufficient evidence to support the use of VFL in the second-line setting. Randomized trials comparing VFL with combinations most commonly used, such as Gemcitabine/paclitaxel and paclitaxel/carboplatin, would establish the clinical utility of VFL. However, such trials would necessarily be large in order to prove superiority of one regimen to another.

\section{Conclusion}

There is currently no standard second-line treatment for managing cisplatin-resistant metastatic UC. Most single agents have yielded unimpressive results, and combination regimens have shown improved response rates and OS, but also greater toxicity. Previous studies have shown the importance of prognostic factors such as chemosensitivity to first-line therapy ${ }^{86}$ or the presence of visceral metastasis, ${ }^{32}$ making comparisons among smaller trials difficult given their necessarily more heterogeneous patient populations.

VFL is the first chemotherapeutic agent to be evaluated in a large UC second-line population: the phase II and III trials included a total of 572 patients. In these studies, VFL has demonstrated relevant clinical activity and, perhaps more importantly, an acceptable and manageable toxicity profile in advanced and refractory disease. Approval of VFL in this setting would provide a safe and moderately effective standard of care against which other single agents or combination regimens could be compared.

\section{Disclosure}

The authors report no conflicts of interest.

\section{References}

1. Jemal A, Siegel R, Ward E, Hao Y, Xu J, Thun MJ. Cancer statistics, 2009. CA Cancer J Clin. 2009;59(4):225-249.

2. Parkin DM, Bray F, Ferlay J, Pisani P. Global cancer statistics, 2002. CA Cancer J Clin. 2005;55(2):74-108.

3. Kirkali Z, Chan T, Manoharan M, et al. Bladder cancer: epidemiology, staging and grading, and diagnosis. Urology. 2005;66(6 Suppl 1):4-34.

4. Brennan P, Bogillot O, Cordier S, et al. Cigarette smoking and bladder cancer in men: a pooled analysis of 11 case-control studies. Int J Cancer. 2000;86(2):289-294.

5. Howe GR, Burch JD, Miller AB, et al. Tobacco use, occupation, coffee, various nutrients, and bladder cancer. J Natl Cancer Inst. 1980;64(4):701-713.

6. Hartge P, Silverman D, Hoover R, et al. Changing cigarette habits and bladder cancer risk: a case-control study. J Natl Cancer Inst. 1987;78(6):1119-1125. 
7. Augustine A, Hebert JR, Kabat GC, Wynder EL. Bladder cancer in relation to cigarette smoking. Cancer Res. 1988;48(15):4405-4408.

8. Burch JD, Rohan TE, Howe GR, et al. Risk of bladder cancer by source and type of tobacco exposure: a case-control study. Int J Cancer. 1989; 44(4):622-628.

9. Clavel J, Cordier S, Boccon-Gibod L, Hemon D. Tobacco and bladder cancer in males: increased risk for inhalers and smokers of black tobacco. Int J Cancer. 1989;44(4):605-610.

10. Engeland A, Andersen A, Haldorsen T, Tretli S. Smoking habits and risk of cancers other than lung cancer: 28 years' follow-up of 26,000 Norwegian men and women. Cancer Causes Control. 1996;7(5): 497-506.

11. Chiou HY, Chiou ST, Hsu YH, et al. Incidence of transitional cell carcinoma and arsenic in drinking water: a follow-up study of 8,102 residents in an arseniasis-endemic area in northeastern Taiwan. Am J Epidemiol. 2001;153(5):411-418.

12. Rahman MM, Ng JC, Naidu R. Chronic exposure of arsenic via drinking water and its adverse health impacts on humans. Environ Geochem Health. 2009;31(Suppl 1):189-200.

13. de Vocht F, Sobala W, Wilczynska U, Kromhout H, SzeszeniaDabrowska N, Peplonska B. Cancer mortality and occupational exposure to aromatic amines and inhalable aerosols in rubber tire manufacturing in Poland. Cancer Epidemiol. 2009;33(2):94-102.

14. Gan J, Skipper PL, Gago-Dominguez M, et al. Alkylaniline-hemoglobin adducts and risk of non-smoking-related bladder cancer. J Natl Cancer Inst. 2004;96(19):1425-1431.

15. Bedwani R, Renganathan E, El Kwhsky F, et al. Schistosomiasis and the risk of bladder cancer in Alexandria, Egypt. $\mathrm{Br} J$ Cancer. 1998;77(7):1186-1189.

16. Kantor AF, Hartge P, Hoover RN, Fraumeni JF Jr. Epidemiological characteristics of squamous cell carcinoma and adenocarcinoma of the bladder. Cancer Res. 1988;48(13):3853-3855.

17. Amling CL. Diagnosis and management of superficial bladder cancer. Curr Probl Cancer. 2001;25(4):219-278.

18. Heney NM. Natural history of superficial bladder cancer. Prognostic features and long-term disease course. Urol Clin North Am. 1992;19(3):429-433.

19. von der Maase H, Hansen SW, Roberts JT, et al. Gemcitabine and cisplatin versus methotrexate, vinblastine, doxorubicin, and cisplatin in advanced or metastatic bladder cancer: results of a large, randomized, multinational, multicenter, phase III study. J Clin Oncol. 2000;18(17):3068-3077.

20. McCaffrey JA, Hilton S, Mazumdar M, et al. Phase II trial of docetaxel in patients with advanced or metastatic transitional-cell carcinoma. J Clin Oncol. 1997;15(5):1853-1857.

21. Papamichael D, Gallagher CJ, Oliver RT, Johnson PW, Waxman J. Phase II study of paclitaxel in pretreated patients with locally advanced/ metastatic cancer of the bladder and ureter. Br J Cancer. 1997; 75(4):606-607.

22. Vaughn DJ, Broome CM, Hussain M, Gutheil JC, Markowitz AB. Phase II trial of weekly paclitaxel in patients with previously treated advanced urothelial cancer. J Clin Oncol. 2002;20(4):937-940.

23. Joly F, Houede N, Noal S, et al. Do patients with advanced urothelial carcinoma benefit from weekly paclitaxel chemotherapy? A GETUG Phase II Study. Clin Genitourin Cancer. 2009;7(2):E28-E33.

24. Sweeney CJ, Roth BJ, Kabbinavar FF, et al. Phase II study of pemetrexed for second-line treatment of transitional cell cancer of the urothelium. J Clin Oncol. 2006;24(21):3451-3457.

25. Galsky MD, Mironov S, Iasonos A, Scattergood J, Boyle MG, Bajorin DF. Phase II trial of pemetrexed as second-line therapy in patients with metastatic urothelial carcinoma. Invest New Drugs. 2007;25(3):265-270.

26. Gomez-Abuin G, Winquist E, Stadler WM, et al. A phase II study of PS-341 (Bortezomib) in advanced or metastatic urothelial cancer. A trial of the Princess Margaret Hospital and University of Chicago phase II consortia. Invest New Drugs. 2007;25(2):181-185.
27. Rosenberg JE, Halabi S, Sanford BL, et al. Phase II study of bortezomib in patients with previously treated advanced urothelial tract transitional cell carcinoma: CALGB 90207. Ann Oncol. 2008;19(5):946-950.

28. Blumenreich MS, Yagoda A, Natale RB, Watson RC. Phase II trial of vinblastine sulfate for metastatic urothelial tract tumors. Cancer. 1982;50(3):435-438.

29. Vaishampayan UN, Faulkner JR, Small EJ, et al. Phase II trial of carboplatin and paclitaxel in cisplatin-pretreated advanced transitional cell carcinoma: a Southwest Oncology Group study. Cancer. 2005;104(8):1627-1632.

30. Kouno T, Ando M, Yonemori K, et al. Weekly paclitaxel and carboplatin against advanced transitional cell cancer after failure of a platinumbased regimen. Eur Urol. 2007;52(4):1115-1122.

31. Soga N, Onishi T, Arima K, Sugimura Y. Paclitaxel carboplatin chemotherapy as a second-line chemotherapy for advanced platinum resistant urothelial cancer in Japanese cases. Int J Urol. 2007; 14(9):828-832.

32. Sternberg CN, Calabro F, Pizzocaro G, Marini L, Schnetzer S, Sella A. Chemotherapy with an every-2-week regimen of gemcitabine and paclitaxel in patients with transitional cell carcinoma who have received prior cisplatin-based therapy. Cancer. 2001;92(12):2993-2998.

33. Fechner G, Siener R, Reimann M, Kobalz L, Albers P. Randomised phase II trial of gemcitabine and paclitaxel second-line chemotherapy in patients with transitional cell carcinoma (AUO Trial AB 20/99). Int $J$ Clin Pract. 2006;60(1):27-31.

34. Matsumoto K, Irie A, Satoh T, Okazaki M, Iwamura M, Baba S. Gemcitabine and paclitaxel chemotherapy as a second-line treatment for advanced or metastatic urothelial carcinoma. Int $J$ Urol. 2007;14(11):1000-1004; discussion 04.

35. Kanai K, Kikuchi E, Ohigashi T, et al. Gemcitabine and paclitaxel chemotherapy for advanced urothelial carcinoma in patients who have received prior cisplatin-based chemotherapy. Int J Clin Oncol. 2008;13(6):510-514.

36. Suyama T, Ueda T, Fukasawa S, et al. Combination of gemcitabine and paclitaxel as second-line chemotherapy for advanced urothelial carcinoma. Jpn J Clin Oncol. 2009;39(4):244-250.

37. Fahy J, Hellier P, Breillout F, Bailly C. Vinflunine: discovery and synthesis of a novel microtubule inhibitor. Semin Oncol. 2008; 35(3 Suppl 3):S3-S5.

38. Bennouna J, Delord JP, Campone M, Nguyen L. Vinflunine: a new microtubule inhibitor agent. Clin Cancer Res. 2008;14(6):1625-1632.

39. Bennouna J, Fumoleau P, Armand JP, et al. Phase I and pharmacokinetic study of the new vinca alkaloid vinflunine administered as a 10-min infusion every 3 weeks in patients with advanced solid tumours. Ann Oncol. 2003;14(4):630-637.

40. Bennouna J, Campone M, Delord JP, Pinel MC. Vinflunine: a novel antitubulin agent in solid malignancies. Expert Opin Investig Drugs. 2005;14(10):1259-1267.

41. Johnson P, Geldart T, Fumoleau P, Pinel MC, Nguyen L, Judson I. Phase I study of vinflunine administered as a 10-minute infusion on days 1 and 8 every 3 weeks. Invest New Drugs. 2006;24(3):223-231.

42. Teicher BA. Newer cytotoxic agents: attacking cancer broadly. Clin Cancer Res. 2008;14(6):1610-1617.

43. Jordan MA, Horwitz SB, Lobert S, Correia JJ. Exploring the mechanisms of action of the novel microtubule inhibitor vinflunine. Semin Oncol. 2008;35(3 Suppl 3):S6-S12.

44. Kruczynski A, Barret JM, Etievant C, Colpaert F, Fahy J, Hill BT. Antimitotic and tubulin-interacting properties of vinflunine, a novel fluorinated Vinca alkaloid. Biochem Pharmacol. 1998;55(5):635-648.

45. Kruczynski A, Hill BT. Vinflunine, the latest Vinca alkaloid in clinical development. A review of its preclinical anticancer properties. Crit Rev Oncol Hematol. 2001;40(2):159-173.

46. Lobert S, Ingram JW, Hill BT, Correia JJ. A comparison of thermodynamic parameters for vinorelbine- and vinflunine-induced tubulin self-association by sedimentation velocity. Mol Pharmacol. 1998;53(5):908-915. 
47. Lobert S, Puozzo C. Pharmacokinetics, metabolites, and preclinical safety of vinflunine. Semin Oncol. 2008;35(3 Suppl 3):S28-S33.

48. Etievant C, Barret JM, Kruczynski A, Perrin D, Hill BT. Vinflunine (20',20'-difluoro-3',4'-dihydrovinorelbine), a novel Vinca alkaloid, which participates in P-glycoprotein (Pgp)-mediated multidrug resistance in vivo and in vitro. Invest New Drugs. 1998;16(1):3-17.

49. Etievant C, Kruczynski A, Barret JM, Tait AS, Kavallaris M, Hill BT. Markedly diminished drug resistance-inducing properties of vinflunine (20',20'-difluoro-3', $4^{\prime}$ '-dihydrovinorelbine) relative to vinorelbine, identified in murine and human tumour cells in vivo and in vitro. Cancer Chemother Pharmacol. 2001;48(1):62-70.

50. Kruczynski A, Poli M, Dossi R, et al. Anti-angiogenic, vascular-disrupting and anti-metastatic activities of vinflunine, the latest vinca alkaloid in clinical development. Eur J Cancer. 2006;42(16):2821-2832.

51. Kruczynski A, Colpaert F, Tarayre JP, Mouillard P, Fahy J, Hill BT. Preclinical in vivo antitumor activity of vinflunine, a novel fluorinated Vinca alkaloid. Cancer Chemother Pharmacol. 1998; 41(6):437-447.

52. Hill BT, Fiebig HH, Waud WR, Poupon MF, Colpaert F, Kruczynski A. Superior in vivo experimental antitumour activity of vinflunine, relative to vinorelbine, in a panel of human tumour xenografts. Eur J Cancer. 1999;35(3):512-520.

53. Bonfil RD, Russo DM, Binda MM, Delgado FM, Vincenti M. Higher antitumor activity of vinflunine than vinorelbine against an orthotopic murine model of transitional cell carcinoma of the bladder. Urol Oncol. 2002;7(4):159-166.

54. Wolf S, Barton D, Kottschade L, Grothey A, Loprinzi C. Chemotherapyinduced peripheral neuropathy: prevention and treatment strategies. Eur J Cancer. 2008;44(11):1507-1515.

55. Barret JM, Etievant C, Hill BT. In vitro synergistic effects of vinflunine, a novel fluorinated vinca alkaloid, in combination with other anticancer drugs. Cancer Chemother Pharmacol. 2000;45(6):471-476.

56. Hill BT, Barret JM, Fahy J, Kruczynski A. In vitro and in vivo synergistic and additive effects of vinflunine, a novel fluorinated vinca alkaloid currently in phase ii trials, in combination with other anticancer drugs. Proc Am Soc Clin Oncol. 2001;20.

57. Shnyder SD, Cooper PA, Gyselinck N, Hill BT, Double JA, Bibby MC. Vinflunine potentiates the activity of cisplatin but not 5-fluorouracil in a transplantable murine adenocarcinoma model. Anticancer Res. 2003;23(6C):4815-4820.

58. Braguer D, Barret JM, McDaid H, Kruczynski A. Antitumor activity of vinflunine: effector pathways and potential for synergies. Semin Oncol. 2008;35(3 Suppl 3):S13-S21.

59. Simoens C, Vermorken JB, Korst AE, et al. Cell cycle effects of vinflunine, the most recent promising Vinca alkaloid, and its interaction with radiation, in vitro. Cancer Chemother Pharmacol. 2006;58(2):210-218.

60. Yardley DA, McLeod M, Rubin MS, et al. Final results of a first line multicenter phase II metastatic breast cancer trial of Vinflunine monotherapy and in combination with trastuzumab in HER2+ patients. Cancer Res. 2009;69(Suppl 2):252s-Abst.3148.

61. Machiels JP, Chollet P, Taleb A, et al. A dose-finding and pharmacokinetic study of I.V. Vinflunine in combination with Doxorubicin as first line treatment of metastatic breast cancer. Cancer Res. 2009; 69(Suppl 2):396s-Abst.6124.

62. Fumoleau P, Cortes-Funes H, Taleb AB, et al. Phase 2 Study of SingleAgent IV Vinflunine as Third-Line Treatment of Metastatic Breast Cancer After Failure of Anthracycline-/Taxane- Based Chemotherapy. Am J Clin Oncol. 2009;32(4):375-380.

63. Paridaens R, Wildiers H, Dalenc F, et al. Vinflunine in combination with trastuzumab: an active combination in the treatment of HER2 positive metastatic breast cancer. Breast Cancer Res Treat. 2007; 106(Suppl 1):s70-Abst.1082.

64. Fumoleau P, Cortes-Funes H, Chan S, Taleb A, Campone M, Pouget JC. Phase II study of i.v. Vinflunine (VFL) as third-line treatment of metastatic breast carcinoma after failure of anthracycline-/taxane-based chemotherapy. Breast Cancer Res Treat. 2006;100(Suppl 1):s279-Abst.6070.
65. Campone M, Fumoleau P, Roche H, et al. A dose-finding pharmacokinetic study of I.V. Vinflunine (VFL) in combination with Capecitabine (CAPE) as second line treatment of metastatic breast cancer (MBC). Breast Cancer Res Treat.2006; 100(Suppl 1):s279-Abst.6069.

66. Peacock NW, Spigel DR, Mainwaring MG, et al. Preliminary results of a multicenter phase II trial of vinflunine (with trastuzumab in HER2+ pts) as first-line treatment in metastatic breast cancer. J Clin Oncol. 2007;25(18 Suppl):1043-

67. Ramlau R, Bennouna J, Tan EH, et al. Phase III study of vinflunine versus docetaxel in patients (pts) with advanced or metastatic non-small cell lung cancer (NSCLC) previously treated with a platinum containing regimen. J Thorac Oncol. 2007;2(8 Suppl 4):s317-Abst.A3-05.

68. Douillard JY, Coudert B, Gridelli C, et al. Phase III study of IV vinflunine (VFL) versus IV docetaxel (DTX) in patients (pts) with advanced or metastatic non-small cell lung cancer (NSCLC) previously treated with a platinum-containing regimen. EJC Suppl. 2007;5(4):358-Abst.6507.

69. Stinchcombe TE, Lee CB, Hayes DN, et al. Preliminary safety and efficacy data of a phase II trial of vinflunine and cetuximab in the second-line treatment of patients with advanced non-small cell lung cancer. J Clin Oncol. 2008;26(15 Suppl):19100.

70. Joppert M, Knapp M, Dakhil SR, Boccia RV, Steis R, Jones CM. A phase II trial of single-agent vinflunine as second-line treatment for advanced non-small cell lung cancer (An International Oncology Network Study, \#I-05-009). J Clin Oncol. 2008;26 (15 Suppl): 19033.

71. Krzakowski M, Douillard J, Ramlau R, et al. Phase III study of vinflunine versus docetaxel in patients (pts) with advanced non-small cell lung cancer (NSCLC) previously treated with a platinum-containing regimen. J Clin Oncol. 2007;25(18 Suppl):7511.

72. Lunin SD, Spigel DR, Hainsworth JD, et al. Phase II trial of vinflunine (VFL) in sensitive and refractory relapsed small-cell lung cancer (SCLC): Updated results. J Clin Oncol. 2008;26 (15 Suppl): 19028.

73. Peyton JD, Spigel DR, Hainsworth JD, et al. Phase II trial of vinflunine in patients with relapsed small cell lung cancer. J Clin Oncol. 2007;25(18 Suppl):18091.

74. Meluch AA, Spigel DR, Burris HA III, et al. Vinflunine (VFL) as salvage chemotherapy in hormone-refractory prostate cancer (HRPC). $J$ Clin Oncol 2008;26(15 Suppl):16059.

75. Kaleta R, Chung HC, Park SR, et al. Single agent IV vinflunine (VFL) in the second-line treatment of patients (pts) with advanced gastric cancer (AGC): Initial results of a phase II trial. J Clin Oncol. 2008;26 (15 Suppl): 15533.

76. Talbot D, Margery J, Dabouis G, et al. Phase II study of Vinflunine in malignant pleural mesothelioma. J. Clin Oncol. 2007;25(30):4751-4756.

77. Olver IN, Byrne MJ, Walpole E, et al. Phase II study of IV vinflunine in patients with chemotherapy naive metastatic malignant melanoma. Eur J Cancer. 2007;43(12):1829-1832.

78. Margery J, Dabouis G, Dark G, et al. Vinflunine (VFL) in first line treatment of malignant pleural mesothelioma (MPM): Final results of a European phase II study. Lung Cancer. 2006;54(Suppl 1):s47-Abst.193.

79. Goldstein D, Ackland SP, Bell DR, et al. Phase II study of vinflunine in patients with metastatic renal cell carcinoma. Invest New Drugs. 2006;24(5):429-434.

80. Mukohara T, Minami H, Nagai S, et al. Phase I study of i.v. Vinflunine (VFL), a novel microtubule inhibitor, given every three weeks in Japanese patients with solid tumors. Proceedings Annual Meeting American Association of Cancer Research 2008;49:Abst.228.

81. Bellmunt J, Theodore C, Demkov T, et al. Phase III trial of vinflunine plus best supportive care compared with best supportive care alone after a platinum-containing regimen in patients with advanced transitional cell carcinoma of the urothelial tract. J Clin Oncol. 2009;27(27):4454-4461.

82. Culine S, Theodore C, De Santis M, et al. A phase II study of vinflunine in bladder cancer patients progressing after first-line platinumcontaining regimen. Br J Cancer. 2006;94(10):1395-1401. 
83. Vaughn DJ, Srinivas S, Stadler WM, et al. Vinflunine in platinum-pretreated patients with locally advanced or metastatic urothelial carcinoma: results of a large phase 2 study. Cancer. 2009;115(18):4110-4117.

84. Bellmunt J, Delgado FM, George C. Clinical activity of vinflunine in transitional cell carcinoma of the urothelium and other solid tumors. Semin Oncol 2008;35(3 Suppl 3):S34-S43.

85. Wulfing C, Machiels JP, Richel DJ, et al. A single-arm, multicenter, open-label phase 2 study of lapatinib as the second-line treatment of patients with locally advanced or metastatic transitional cell carcinoma. Cancer. 2009;115(13):2881-2890.

86. Albers P, Siener R, Hartlein M, et al. Gemcitabine monotherapy as second-line treatment in cisplatin-refractory transitional cell carcinomaprognostic factors for response and improvement of quality of life. Onkologie. 2002;25(1):47-52.

87. Pronzato P, Vigani A, Pensa F, Vanoli M, Tani F, Vaira F. Second line chemotherapy with ifosfamide as outpatient treatment for advanced bladder cancer. Am J Clin Oncol. 1997;20(5):519-521.

88. Witte RS, Elson P, Bono B, et al. Eastern Cooperative Oncology Group phase II trial of ifosfamide in the treatment of previously treated advanced urothelial carcinoma. J Clin Oncol. 1997;15(2):589-593.

89. Witte RS, Manola J, Burch PA, Kuzel T, Weinshel EL, Loehrer PJ Sr. Topotecan in previously treated advanced urothelial carcinoma: an ECOG phase II trial. Invest New Drugs. 1998;16(2):191-195.

90. Dodd PM, McCaffrey JA, Mazumdar M, et al. Phase II trial of pyrazoloacridine as second-line therapy for patients with unresectable or metastatic transitional cell carcinoma. Invest New Drugs. 2000;18(3):247-251.

91. Roth BJ, Manola J, Dreicer R, Graham D, Wilding G. Piritrexim in advanced, refractory carcinoma of the urothelium (E3896): a phase II trial of the Eastern Cooperative Oncology Group. Invest New Drugs. 2002;20(4):425-429.

92. Lassiter LK, Tummala MK, Hussain MH, Stadler WM, Petrylak DP, Carducci MA. Phase II open-label study of oral piritrexim in patients with advanced carcinoma of the urothelium who have experienced failure with standard chemotherapy. Clin Genitourin Cancer. 2008;6(1):31-35.

93. Winquist E, Vokes E, Moore MJ, Schumm LP, Hoving K, Stadler WM. A Phase II study of oxaliplatin in urothelial cancer. Urol Oncol. 2005;23(3):150-154.

94. Akaza H, Naito S, Usami M, Miki T, Miyanaga N, Taniai H. Efficacy and safety of gemcitabine monotherapy in patients with transitional cell carcinoma after Cisplatin-containing therapy: a Japanese experience. Jpn J Clin Oncol. 2007;37(3):201-206.

95. Dreicer R, Li S, Manola J, Haas NB, Roth BJ, Wilding G. Phase 2 trial of epothilone B analog BMS-247550 (ixabepilone) in advanced carcinoma of the urothelium (E3800): a trial of the Eastern Cooperative Oncology Group. Cancer. 2007;110(4):759-763.
96. Beer TM, Goldman B, Nichols CR, et al. Southwest Oncology Group phase II study of irinotecan in patients with advanced transitional cell carcinoma of the urothelium that progressed after platinum-based chemotherapy. Clin Genitourin Cancer. 2008;6(1):36-39.

97. Tu SM, Hossan E, Amato R, Kilbourn R, Logothetis CJ. Paclitaxel, cisplatin and methotrexate combination chemotherapy is active in the treatment of refractory urothelial malignancies. J Urol. 1995; 154(5): 1719-1722.

98. De Mulder PH, Theodore C, Sella A, et al. Phase II EORTC trial with 5-fluorouracil, cisplatin and interferon-alpha as second-line treatment of advanced transitional cell cancer of the urothelial tract. Ann Oncol. 2000;11(11):1391-1394.

99. Krege S, Rembrink V, Borgermann C, Otto T, Rubben H. Docetaxel and ifosfamide as second line treatment for patients with advanced or metastatic urothelial cancer after failure of platinum chemotherapy: a phase 2 study. J Urol. 2001;165(1):67-71.

100. Pectasides D, Aravantinos G, Kalofonos H, et al. Combination chemotherapy with gemcitabine and ifosfamide as second-line treatment in metastatic urothelial cancer. A phase II trial conducted by the Hellenic Cooperative Oncology Group. Ann Oncol. 2001;12(10):1417-1422.

101. Pagliaro LC, Millikan RE, Tu SM, et al. Cisplatin, gemcitabine, and ifosfamide as weekly therapy: a feasibility and phase II study of salvage treatment for advanced transitional-cell carcinoma. J Clin Oncol. 2002;20(13):2965-2970.

102. Dreicer R, Manola J, Schneider DJ, et al. Phase II trial of gemcitabine and docetaxel in patients with advanced carcinoma of the urothelium: a trial of the Eastern Cooperative Oncology Group. Cancer. 2003;97(11):2743-2747.

103. Di Lorenzo G, Autorino R, Giordano A, et al. FOLFOX-4 in pre-treated patients with advanced transitional cell carcinoma of the bladder. Jpn J Clin Oncol. 2004;34(12):747-750.

104. Shinohara N, Harabayashi T, Suzuki S, et al. Salvage chemotherapy with paclitaxel, ifosfamide, and nedaplatin in patients with urothelial cancer who had received prior cisplatin-based therapy. Cancer Chemother Pharmacol. 2006;58(3):402-407.

105. Uhm JE, Lim HY, Kim WS, et al. Paclitaxel with cisplatin as salvage treatment for patients with previously treated advanced transitional cell carcinoma of the urothelial tract. Neoplasia. 2007;9(1):18-22.

106. Lin CC, Hsu CH, Huang CY, et al. Gemcitabine and ifosfamide as a second-line treatment for cisplatin-refractory metastatic urothelial carcinoma: a phase II study. Anticancer Drugs. 2007;18(4):487-491.

107. Han KS, Joung JY, Kim TS, et al. Methotrexate, vinblastine, doxorubicin and cisplatin combination regimen as salvage chemotherapy for patients with advanced or metastatic transitional cell carcinoma after failure of gemcitabine and cisplatin chemotherapy. Br J Cancer. 2008;98(1):86-90.

\section{Publish your work in this journal}

The Open Access Journal of Urology is an international, peer-reviewed, open access journal publishing original research, reports, editorials, reviews and commentaries on all aspects of adult and pediatric urology in the clinic and laboratory including the following topics: Pathology, pathophysiology of urological disease; Investigation and treatment of

\section{Dovepress}

urological disease; Pharmacology of drugs used for the treatment of urological disease. The manuscript management system is completely online and includes a very quick and fair peer-review system, which is all easy to use. Visit http://www.dovepress.com/testimonials.php to read real quotes from published authors. 